\title{
A zöldinfrastruktúra-fejlesztés célterületei Magyarországon
}

\author{
Török Katalin ${ }^{1}$, Csőszi Mónika², Vaszócsik Vilja², Schneller \\ Krisztián ${ }^{2}$, Teleki Mónika², Kollányi László ${ }^{3}$ Keszthelyi Ákos ${ }^{3}$, \\ Máté Klaudia $^{3}$, Csecserits Anikó ${ }^{1}$, Halassy Melinda ${ }^{1}$, \\ Kertész Miklós ${ }^{1}$ és Szitár Katalin ${ }^{1}$ \\ ${ }^{1}$ Ökológiai Kutatóközpont, Ökológiai és Botanikai Intézet, \\ 2163 Vácrátót, Alkotmány u. 2-4. \\ ${ }^{2}$ Lechner Tudásközpont Nonprofit Korlátolt Felelösségü Társaság, \\ 1111 Budapest, Budafoki út 59., 1149 Budapest, Bosnyák tér 5. \\ ${ }^{3}$ Ormos Imre Alapitvány, 1118. Budapest, Villányi út 29-43. \\ E-mail:torok.katalin@ecolres.hu
}

\begin{abstract}
Összefoglaló: A biodiverzitás pusztulásának visszafordítása érdekében a természeti tôke növelésére van szükség. Ennek módját az EU Biodiverzitás Stratégiája a zöldinfrastruktúra fejlesztésében látja. Az országos zöldinfrastruktúra-elemek meghatározása és állapotuk értékelése, valamint a fejlesztési javaslatok kidolgozása három pilléren alapul: az ökológiai állapot, az ökoszisztéma-szolgáltatást nyújtó képesség és a térbeli összekapcsoltság értékelésén. Az itt ismertetett, egy KEHOP projekt keretében végzett kutatás során egységes értékelés készült a térképezett ökoszisztéma-típusokra, ami alapján meghatározták a védelemre, potenciális állapotjavításra vagy ökoszisztématípus-váltásra alkalmas területeket. A potenciális beavatkozási területek - a restauráció célterületei, az ország 88\%-a - tovább priorizálhatók a különbözö konfliktusterületek lehatárolásával. A restauráció során kialakítandó célélőhelyek meghatározása modellezéssel történt. Az eredmények a természetvédelemben és a területhasználatot befolyásoló ágazati döntéshozásban alkalmazhatóak.
\end{abstract}

Kulcsszavak: döntéstámogatás, EU Biodiverzitás Stratégia, konnektivitás, multifunkcionalitás, ökológiai állapot, ökoszisztéma-szolgáltatás, többrétegü potenciális természetes vegetáció modell, területhasználat

\section{Bevezetés}

Cikkünkben a hazai zöldinfrastruktúra-fejlesztés tudományos koncepcióját és első eredményeit foglaljuk össze. Az élővilág rohamos pusztulásának megállításához nem elegendő a jelenlegi védett területek megőrzése, ehhez kiterjedt élőhelyrestaurációs beavatkozásokra van szükség (Aronson és Alexander 2013), 
amit az EU 2030-ig tartó Biodiverzitás Stratégiája (COM[2020] 380 EB) a természet-restaurációs tervében hangsúlyosan meg is fogalmaz (EU Nature Restoration Plan). A 2021. év során pontosítják azokat a jogilag kötelező érvényü feladatokat, melyek megvalósulásának eredményeképpen a 2030-ig tervezett időszakban remélhetőleg jelentős javulást érünk majd el a természetközeli élőhelyek állapotában és növelhetjük a kiterjedésüket. Az európai zöld megállapodás (EU Green Deal) fontos pillére a biodiverzitás-megőrzés szempontjainak beépítése a különböző szakágazatok müködésébe a mezőgazdaságtól az erdészetig, a közlekedéstől az oktatásig (COM[2019] 640 EB). Csak a természeti tőke (Czúcz et al. 2012) megőrzésével, növelésével valósulhat meg az a jelentős ágazati, kormányzási átalakulást igénylő jövőkép, mely Európát globális vezetővé teheti a környezeti és a biodiverzitás-krízis kezelésében.

A nagyratörö tervek szerint az ökoszisztémák állapotjavítását és kiterjedésének növelését a zöldinfrastruktúra- (továbbiakban ZI) fejlesztés alapozza meg, melyre vonatkozóan az EU szintén kidolgozott egy stratégiát (COM[2013] 249 EB). A stratégia a természeti tőkénk eddigi sikertelen megóvásának problémáját abban látja, hogy a természet által nyújtott javakat, az ún. ökoszisztéma-szolgáltatásokat úgy használtuk, mintha azok kimeríthetetlenek lennének. A megoldás csak az ökoszisztéma-szolgáltatások ésszerü és takarékos használata, a szolgáltatást biztosító ökoszisztémák (a természeti tőke) megóvása, helyreállítása és fejlesztése lehet, melynek eszköze a ZI, mely egyben a klímaváltozással szembeni adaptáció egyik fontos eszköze is (COM[2021] $82 \mathrm{~EB})$. A ZI a természetes és félig természetes területek, valamint növényzettel fedett és ökológiai funkciót betöltő egyéb tájelemek olyan stratégiailag megtervezett hálózata, mely széleskörü ökoszisztéma-szolgáltatások nyújtására képes a vidéki és városi környezetben egyaránt. Ez a meghatározás az EU zöldinfrastruktúra stratégiáján alapul (COM[2013] 249 EB), megjegyezzük azonban, hogy számos más megfogalmazás is napvilágot látott.

A ZI-fejlesztés célkitüzéseinek meghatározása a ZI alapállapot-értékelése alapján történik, amiröl részletesebben ebben a kötetben olvashatnak (Szitár et al. 2021). A ZI-állapotértékelés és -fejlesztés közös alapja három fö szempont vagy értékelési tengely, mely a ZI definíciójából következik: az ökoszisztémák ökológiai állapota, a térbeli összekapcsoltságuk (konnektivitásuk), valamint az általuk nyújtott ökoszisztéma-szolgáltatások és azok mennyisége, amelyeket multifunkcionalitásként értékelünk. A ZI-fejlesztési javaslatok segítik az élővilág megőrzése és a szakágazatok célrendszere közötti kapcsolat megteremtését oly módon, hogy tudományosan megalapozott javaslatokat fogalmaznak meg. A ZI-fejlesztési javaslatok célterületeinek konkrét térbeli lehatárolása segíti a területhasználatot jelentősen befolyásoló - pl. a mezőgazdaság, vízgazdálkodás, erdőgazdálkodás, terület- és településfejlesztés területén dolgozó - ágazati döntésho- 
zók munkáját. Az adatokkal megfelelően alátámasztott és az ökológiai szemléletet tükröző ZI-fejlesztési javaslattal van esély a természeti tőke hanyatlásának visszafordítására, valamint az eddigi sikertelen erőfeszítések helyett a tájhasználatot az ökoszisztéma-szolgáltatásokkal is számoló, fenntartható útra terelni. Ehhez szükséges a fejlesztés megvalósulásának rendszeres monitorozása.

A hazai ZI-állapotértékelés és -fejlesztés tervezéséhez az ökoszisztéma-szolgáltatások értékelése és térképezése adta az alapot (Kovács-Hostyánszki et al. 2019), mely ugyanazon KEHOP projekt (http1) keretében valósult meg. Ennek első lépéseként elkészült Magyarország Ökoszisztéma-alaptérképe $20 \mathrm{~m} \times 20$ m-es megjelenítési felbontással, majd az ökoszisztémák állapotát is becsülték (Tanács et al. 2021), végül ezekre épült a kiválasztott ökoszisztéma-szolgáltatások elemzése és térképezése. Összesen hat országos és öt települési, szabályozó vagy kulturális típusú ökoszisztéma-szolgáltatás indikátort vettek figyelembe. A ZI-állapotértékelés ezen elemzések felhasználásával készült. A ZI-fejlesztési javaslatok célja az alapállapot-értékelés alapján lokalizált fejlesztési prioritások meghatározása egy egységes koncepció mentén, mely alapot adhat a természetvédelmi és egyéb érintett ágazati fejlesztésekhez. A ZI-fejlesztési koncepció részletes leírása a projekt keretében készült jelentésben található (Csőszi et al. 2021), itt a legfontosabb módszertani fejlesztéseket és eredményeket mutatjuk be, melyek a gyakorlati felhasználás irányába is utat mutathatnak.

\section{Anyag és módszer}

A ZI-állapotértékelés az állapottér mindhárom tengelyén (az ökológiai állapot, az ökoszisztéma-szolgáltatás és a térbeli összekapcsoltság) egy adott terület ötféle értéket vehet fel (1-5), ahol a legjobbat az 5 jelzi. A ZI-állapottérkép megmutatja, hogy az egyes térképcellákra vonatkozóan a három tengely milyen értéket vesz fel (a térképet ld. Szitár et al. 2021). Könnyü belátni, hogy a három dimenzióban felvehetö öt érték túl sok kombinációs kategóriát eredményez, így ezek összevonásokkal kerültek ábrázolásra, úgy, hogy az ökoszisztéma-szolgáltatás (vagy multifunkcionalitás) három, míg a konnektivitás két értéket vehet fel. A fejlesztés elve, hogy a rosszabb állapotból a jobb állapotba való elmozdulás kívánatos az állapottérben. Az elmozdulások azonban nem azonos értéküek, mivel a három tengely szerinti állapot értékei nem teljesen függetlenek egymástól. Az ökológiai állapot összefüggésben áll az ökoszisztéma konnektivitásával, hiszen az elszigetelődés hosszú távon mindenképpen az ökológiai állapot leromlásával jár, és fordítva, több és jobb állapotú ökoszisztéma jobb átjárhatóságot biztosít a tájban. Az ökológiai állapottengelyt kiemelten kezeltük, mert ezt a tényezőt tartjuk a legfon- 
tosabbnak a három közül, minthogy ez képezi a zöldinfrastruktúra minden funkciójának alapját, így a zöldinfrastruktúra-fejlesztés fó beavatkozási típusainak lehatárolását elsődlegesen ezen tengely alapján végeztük. Ezen az alapon az ötös ökológiai állapotú területeket elkülönítettük, itt nem szükséges fejlesztési beavatkozás, csak fenntartás és megőrzés (1. ábra). Ezen belül, ahol a másik két jellemző is magas értéket vesz fel, azok tekinthetők a legjobb állapotú ZI-területeknek.

Minden területet, ahol az ökológiai állapot nem ötös értékủ, potenciális beavatkozási területnek tekintünk. Ezen belül elkülönítettük a csak állapotjavításra és az ökoszisztématípus-váltásra is alkalmas területeket (sárga és piros színnel jelölve az ábrán). Ez a beosztás nem automatikusan, hanem ökoszisztéma-specifikusan történt, minden egyes átmenet elemzésével, szakértöi döntés segítségével (részletesen lásd Csőszi et al. 2021). Az elkülönítés logikai sémáját a 2. ábra mutatja be. Az eredmény a ZI-fejlesztés szempontjából három lehetséges kimenet: (1) védelemre, (2) potenciális állapotjavításra, ill. (3) ökoszisztéma-váltásra alkalmas területek lehatárolása. Ezen kívül a fejlesztési javaslat tartalmazza a magas ökológiai állapotú területek térbeli összekapcsoltságának javítását célzó tájökológiai folyosók lehetséges helyét is.

A kiváló és jó ökológiai állapotú területek közötti kapcsolatok fejlesztésének lehatárolásához a „legkisebb költség útvonal” (Least Cost Path, Zhang et al. 2018) térinformatikai módszerét használtuk. Ennek alapja a „költség-” vagy ellenállástérkép elkészítése, ahol minden térképi pontnak (pixelnek) van egy költségértéke, amely a területen történő ,áthaladás" nehézségével van arányban. Az ellenállástérkép készítése során az Ökoszisztéma-alaptérkép kategóriáit „költség” szempontjából 1 és 100 között újraosztályoztuk: a legmagasabb értékü területek az urbánus területek, legalacsonyabbak a természetközeli erdős, vizes és gyepterületek. Az egyes pontokon áthaladva így bizonyos értékkel mindig növekszik a költség, és a két pontot összekötő potenciális útvonalak között mindig meghatározható a „legalacsonyabb költségü" útvonal. Az összekötő vonalakat a 15 hektárnál nagyobb, jó és kiváló ökológiai állapotú csomópontok között határoztuk meg úgy, hogy a tervezett folyosó a három legközelebbi szomszédot kapcsolja össze legfeljebb 30 km-es távolságban. Országos szinten, konkrét fajok igényeinek meghatározása nélkül az elemzés eredménye inkább egy általános, potenciális ökofolyosó elemzésnek tekinthetö.

Az ökológiai szempontból indokolható potenciális beavatkozások az ország jelentős területét lefedik (8,2 millió hektár, $88 \%)$, ezért szükséges a fejlesztések priorizálása. Ennek érdekében meghatároztuk azokat a környezeti és területhasználati konfliktusokat, amelyek alapján beavatkozási fókuszterületek javasolhatók. A vizsgált környezeti konfliktusok, ill. konfliktussal érintett területek a következők: belvíz-veszélyeztetettség, vízminőség-védelmi területen lévő szántók, 
Fenntartás - ökológiai állapotjavítás- élőhelyváltás

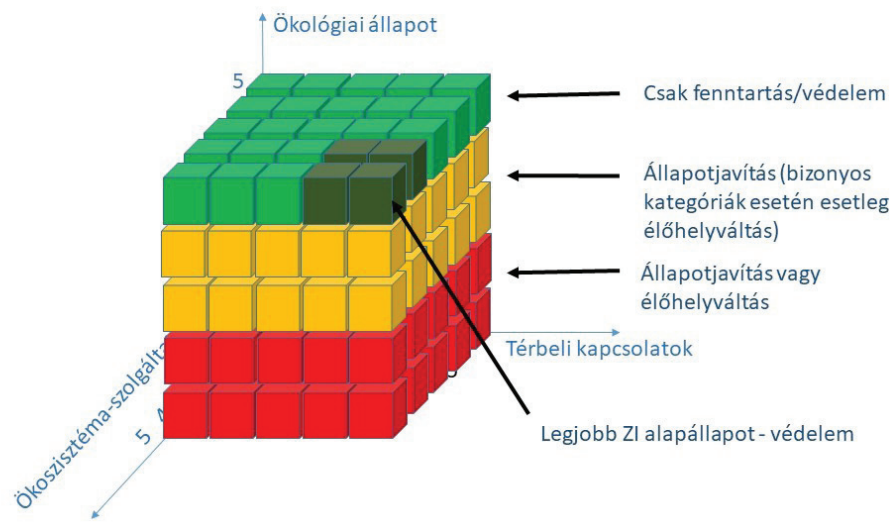

1. ábra. A három állapotértékelési tengely mentén kialakuló állapottér az ötfokozatú értékelés mentén, amely kijelöli, hogy az egyes (különböző színekkel jelölt) térrészekben a zöldinfrastruktúra-elemek milyen állapotban vannak, és milyen irányba, milyen módon fejleszthetők.

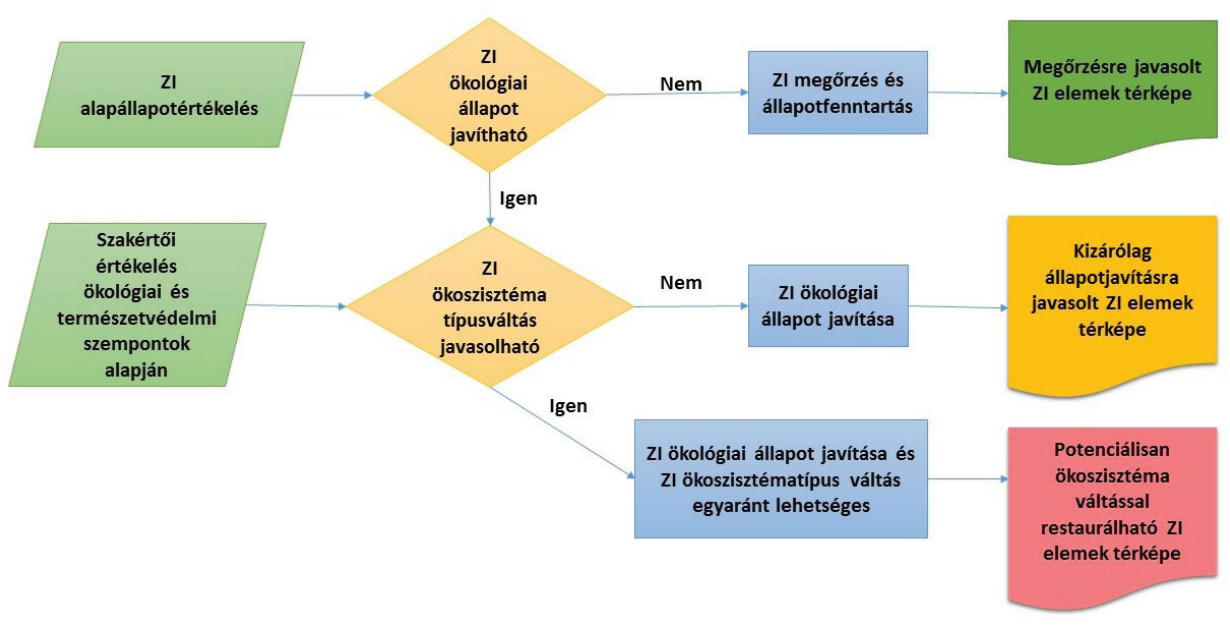

2. ábra. A zöldinfrastruktúra-fejlesztés logikai sémája és három fő kimenete, amelyek megmutatják, hogy hol elsődleges a megörzés (megörzés-térkép), illetve hol lehet javítani a zöldinfrastruktúra állapotát élőhelyváltással vagy anélkül. 
deflációérzékeny területek, erózió-veszélyeztetett területek, faültetvények. A faültetvények fele ma védett területen található, így indokolt konfliktusterületként elemezni ezeket. A vizsgált konfliktusok összemetszésével összesített környezeti konfliktustérképet állítottunk elö, melyen a pixelek 0-5 értéket vehetnek fel. Az értékek a konfliktusok számával és mértékével arányosak (Csőszi et al. 2021). A ZI-fejlesztések elindítását elsősorban ezeken a konfliktusokkal érintett területeken javasoljuk, hiszen ebben az esetben az élőhelyek állapotjavításával emelhető azok ökoszisztéma-szolgáltatásainak mennyisége és minősége is, amellyel a társadalmi-gazdasági hasznuk is többszörösen jelentkezhet.

Nem álltunk meg a potenciális ZI-fejlesztési területek lehatárolásánál, arra is választ kerestünk, hogy az ökoszisztéma-váltás esetén milyen élőhelytípus kialakítása reális. A célélőhelyek lehetséges előfordulási térképét az Ökoszisztémaalaptérkép kategóriáinál finomabb beosztású, Á-NÉR élőhelytípusokra készült, többrétegü potenciális természetes vegetációmodell (MPNV) felhasználásával jelöltük ki (Somodi et al. 2017). (Megjegyezzük, hogy a fentiek miatt az Ökoszisztéma-alaptérkép kategóriáival kapcsolatos szövegben az ökoszisztéma, míg az ÁNÉR élőhelytípusokhoz köthető leírásokban az élőhely szót alkalmazzuk.) A modell 47 élőhelytípusra adja meg a potenciális előfordulási térképet a jelenlegi klimatikus és környezeti viszonyokra, így adott helyre megadható a legvalószínübb előfordulási esélyü élőhelyek listája. A potenciális élőhelyváltásra vonatkozó fejlesztési javaslatot priorizáltuk a fenti konfliktustérképek alapján, ebből mintaként az Ökoszisztéma-alaptérkép összes, összevont gyeptípusára vonatkozó lehetséges restaurációs területet (ökoszisztéma-váltást) ábrázoló térképet mutatjuk be.

\section{Eredmények}

A védelemre javasolt, kiváló ZI-állapotú területek az ország 5\%-át (kb. 460 ezer hektárt) borítják, melyből 320 ezer hektáron az ökoszisztémák konnektivitása és ökoszisztéma-szolgáltatása (multifunkcionalitása) is jó (4 vagy 5 értékü) (3. ábra). A kizárólag potenciális állapotjavításra javasolt területeken az ökológiai állapot jó (4) vagy közepes (3). Itt erdők, gyepek és vizes élőhelyek többé-kevésbé leromlott állományai jellemzők (4. ábra), a térképen az élőhelyi besorolást is megadjuk. Az ökoszisztématípus-váltással potenciálisan fejleszthető terület összesen 6,95 millió hektár, ami megoszlik a legrosszabb ökológiai állapotú (1) területek (4,4 millió ha), a gyenge (2) állapotú (1,5 millió ha) és közepes (3) állapotú területek (1 millió ha) között (5. ábra). Ezen területek nagyobb része jelenleg szántó (4,5 millió ha). 

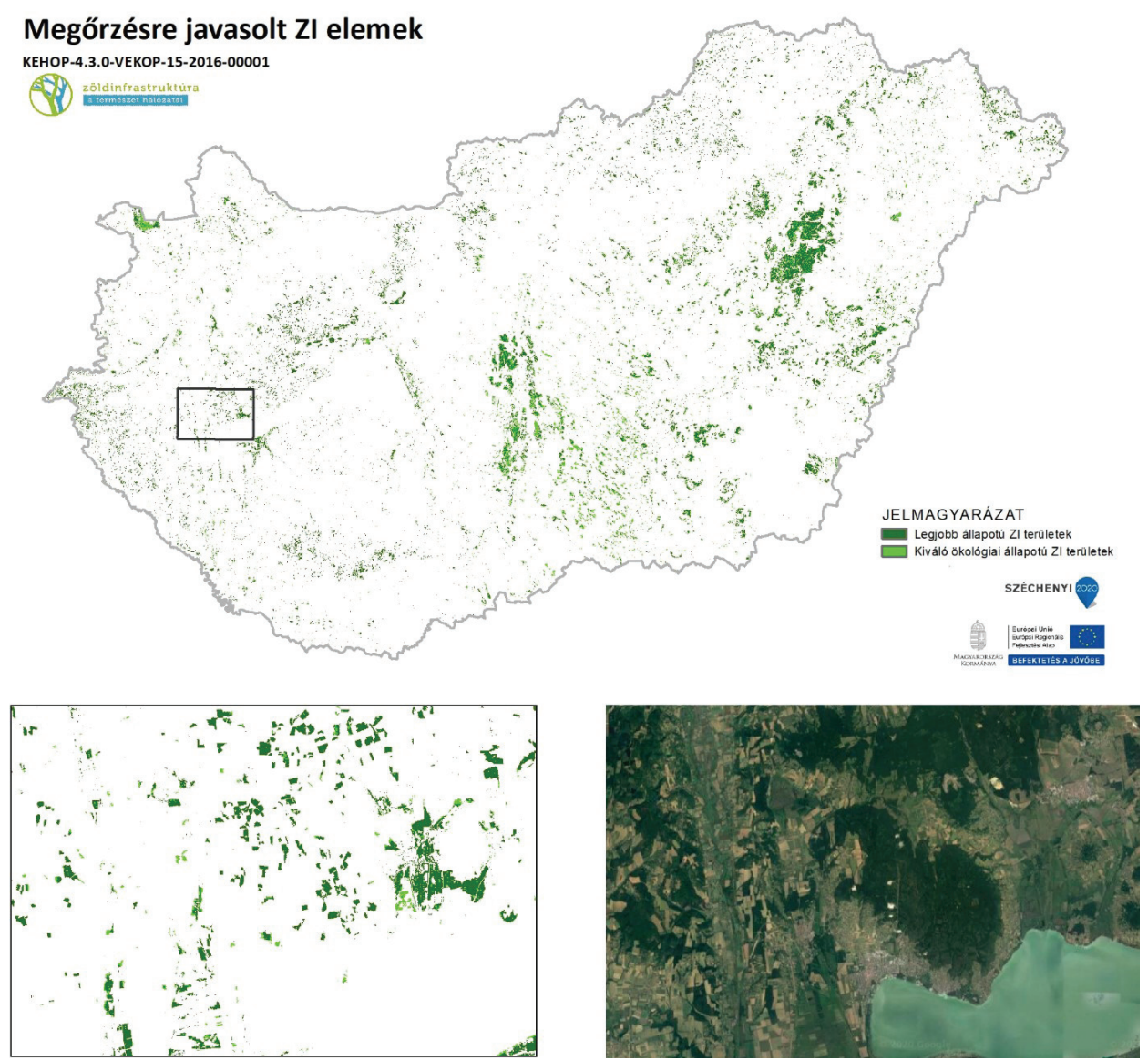

3. ábra. Megörzésre javasolt zöldinfrastruktúra-elemek. Sötétzölddel jeleztük a minden szempontból legkiválóbb területeket. A világosabb zöld területeken az ökológiai állapot kiváló, de a konnektivitás és ökoszisztéma-szolgáltatások szintje lehetne magasabb. A kivágaton mutatjuk a részleteket.

Az ökológiai folyosók területeinek kijelölésére a „legkisebb költség útvonalakból" - a szakirodalmi ajánlások alapján (Weber et al. 2006) - 500 m széles ökológiai folyosót képeztünk (6. ábra). Elsősorban a mezőgazdasági területek lehetnek a fejlesztés célpontjai: potenciálisan 167 ezer hektár szántóterület került lehatárolásra, mint szóba jövő ökológiai folyosó terület.

Az öt elemzett környezeti konfliktusterület összemetszésével súlyozott konfliktusterületeket jelöltünk ki a beavatkozási területre (7. ábra), melyek megmutatják a lehetséges sürgető beavatkozási pontokat, alátámasztva a ZI-fejlesztés priorizálását. 


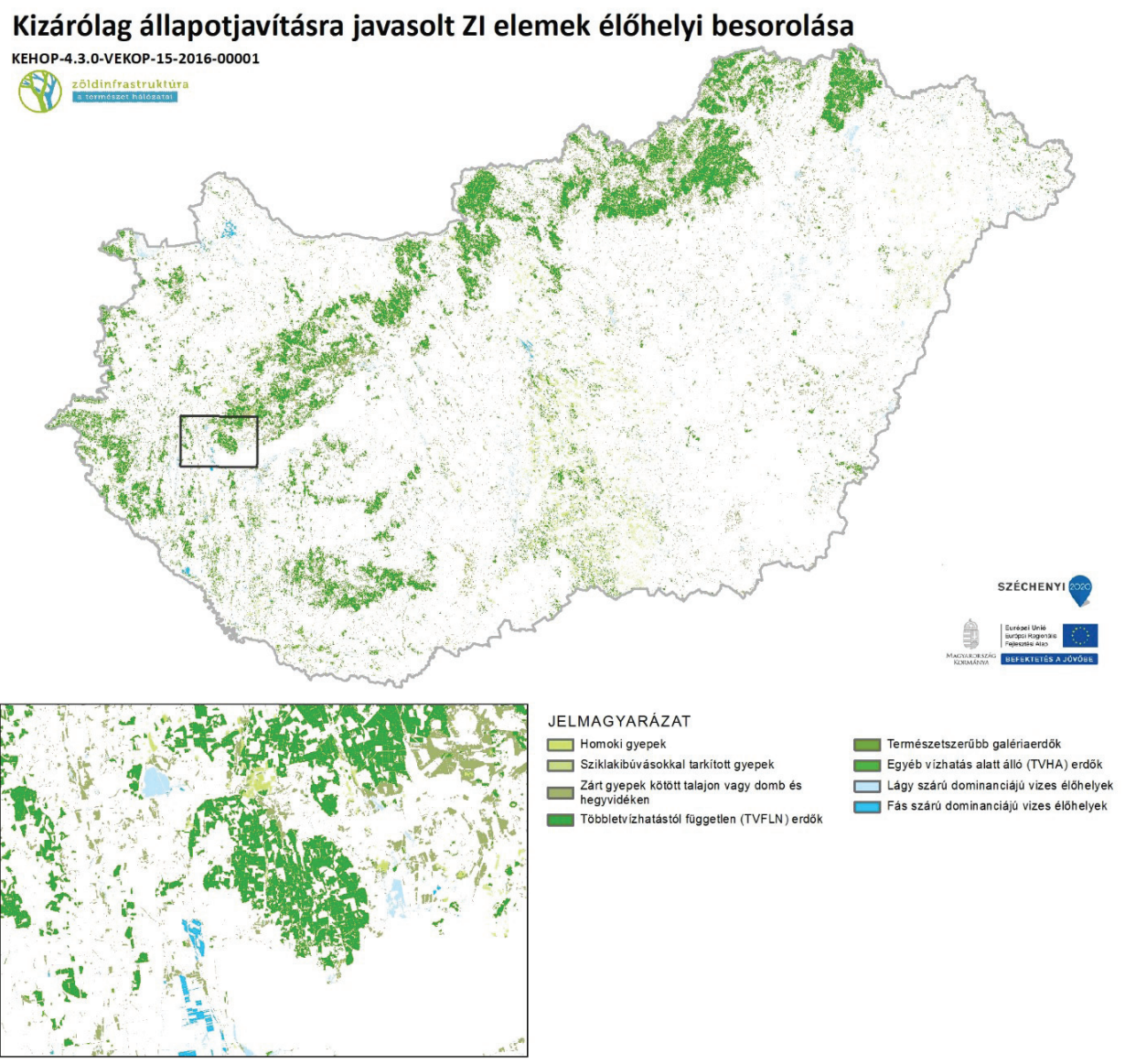

4. ábra. Kizárólag állapotjavításra javasolt zöldinfrastruktúra-elemek élöhelyi besorolása az ökoszisztéma-alaptérkép kategóriái szerint. A fehéren maradt területek olyan foltokat jelölnek, ahol az állapotjavításra nincs szükség vagy lehetőség.

A célélőhely-priorizálás eredményei közül itt azt mutatjuk be, amely a gyepek kialakítására különböző valószínűséggel alkalmas területek és az összesített konfliktustérkép összemetszésével készült (8. ábra). A csaknem hétmillió hektárnyi potenciális gyepi élőhely 57\%-án van egy vagy több általunk vizsgált környezeti konfliktus, azaz restaurációs fókuszterület. Egyes vagy kettes szintü konfliktus 3,2 millió hektárt érint, hármas vagy négyes szintü konfliktus 788 ezer hektárt, míg 11 ezer hektárt ötös szintű konfliktus érint. 

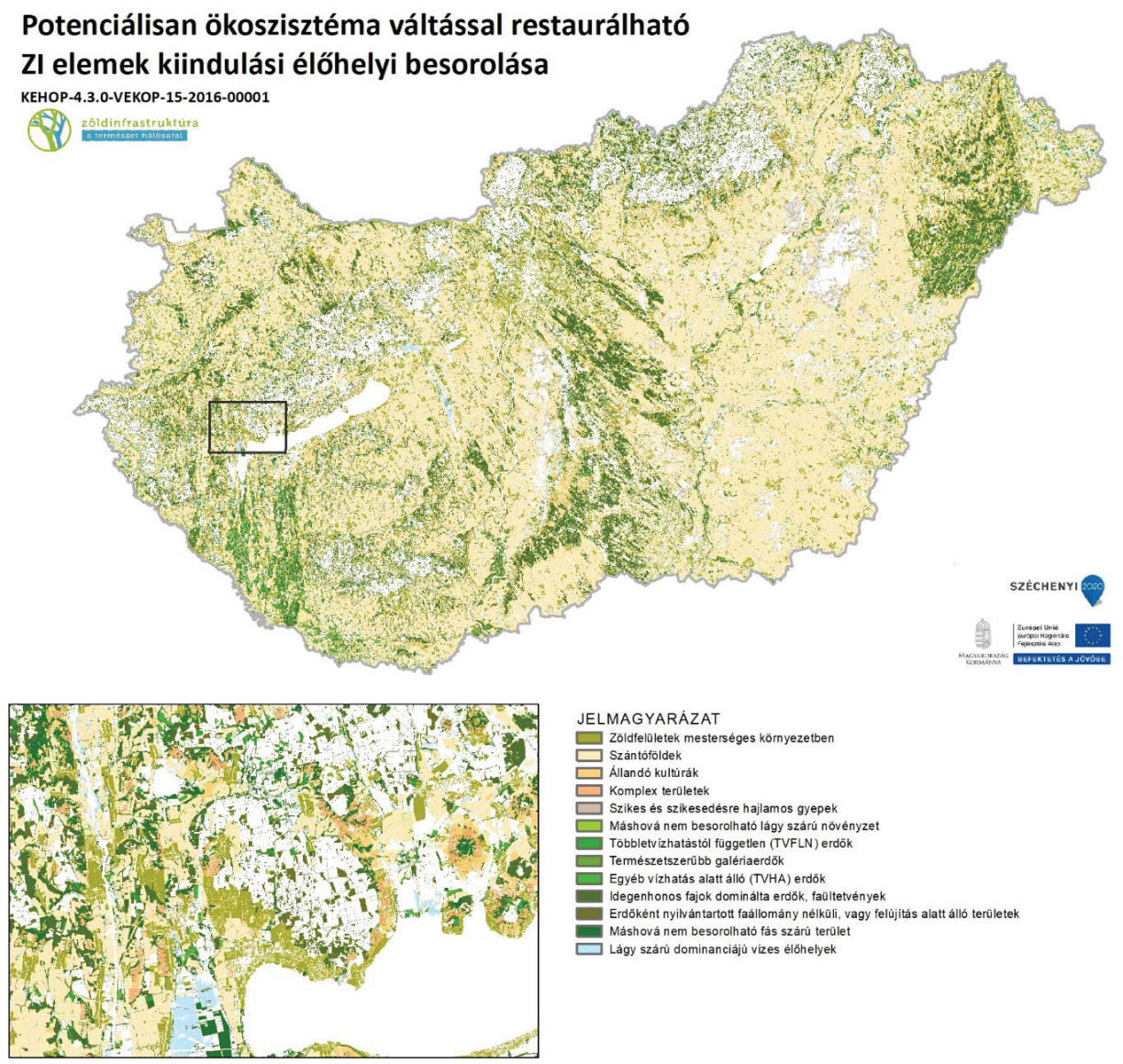

5. ábra. Potenciálisan ökoszisztéma-váltással restaurálható zöldinfrastruktúra-elemek kiindulási élőhelyi besorolása az Ökoszisztéma-alaptérkép kategóriái szerint. A fehéren maradt területek olyan foltokat jelölnek, ahol az ökoszisztéma-váltásra nincs szükség vagy lehetőség.

\section{Diszkusszió}

A ZI-fejlesztési javaslatok eredményei országos léptékben megadják a választ a „hol”, „miért” és „mit” fejlesszünk kérdésekre. A ZI-állapottérkép megadja a „hol” kérdésre a választ, lehatárolja a védelemre, állapotjavításra és az ökoszisztéma-váltásra alkalmas területeket. A ZI-koncepció három tengelye mentén és a konfliktusok jelenléte, vagy a kapcsolatok hiánya alapján minden lokalitásra értelmezhető az ok, ami miatt az adott állapottérbe került. Végül a „mit” kérdésre a célélőhely-priorizálással kaphatunk választ. Az eredmények kiváló alapot adnak ahhoz, hogy integrált megközelítésű, multifunkcionális élőhelykomplexeket tud- 

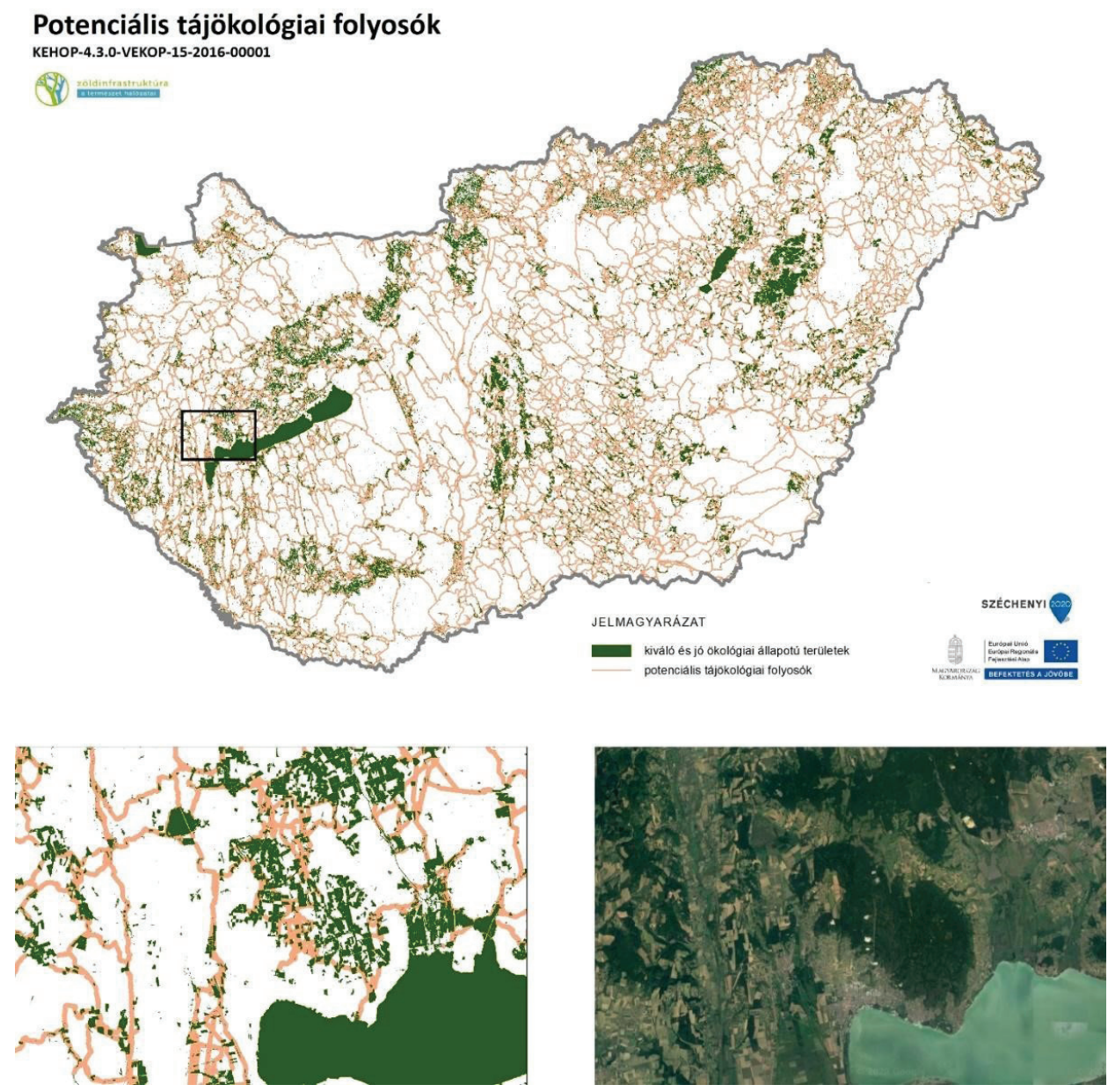

6. ábra. Potenciális tájökológiai folyosók a „legkisebb költség útvonal” modellezésével a kiváló és jó ökológiai állapotú foltok összekötésére.

junk tervezni a biodiverzitás és az ökoszisztéma-szolgáltatások helyreállításának, javításának érdekében. Mivel az ellátó szolgáltatások (pl. élelmiszer) nem szerepeltek a jelen feldolgozásban, ahogy más elemzésekben sem (Hermoso et al. 2020), a termeléssel összefüggő csereviszonyokat a következő kutatási szakaszban kell beépíteni a tervezésbe. A további kutatások másik fontos iránya a felméréseknek az országos léptékről a térségi és lokális szintekre való váltása.

A kutatás hiánypótló, mivel egész országot lefedő, egységes koncepció mentén kidolgozott restaurációs javaslat tudomásunk szerint kevés EU tagállamban készült (pl. Finnország: Kotiaho et al. 2016), és a ZI-fejlesztésekkel kapcsolatos 


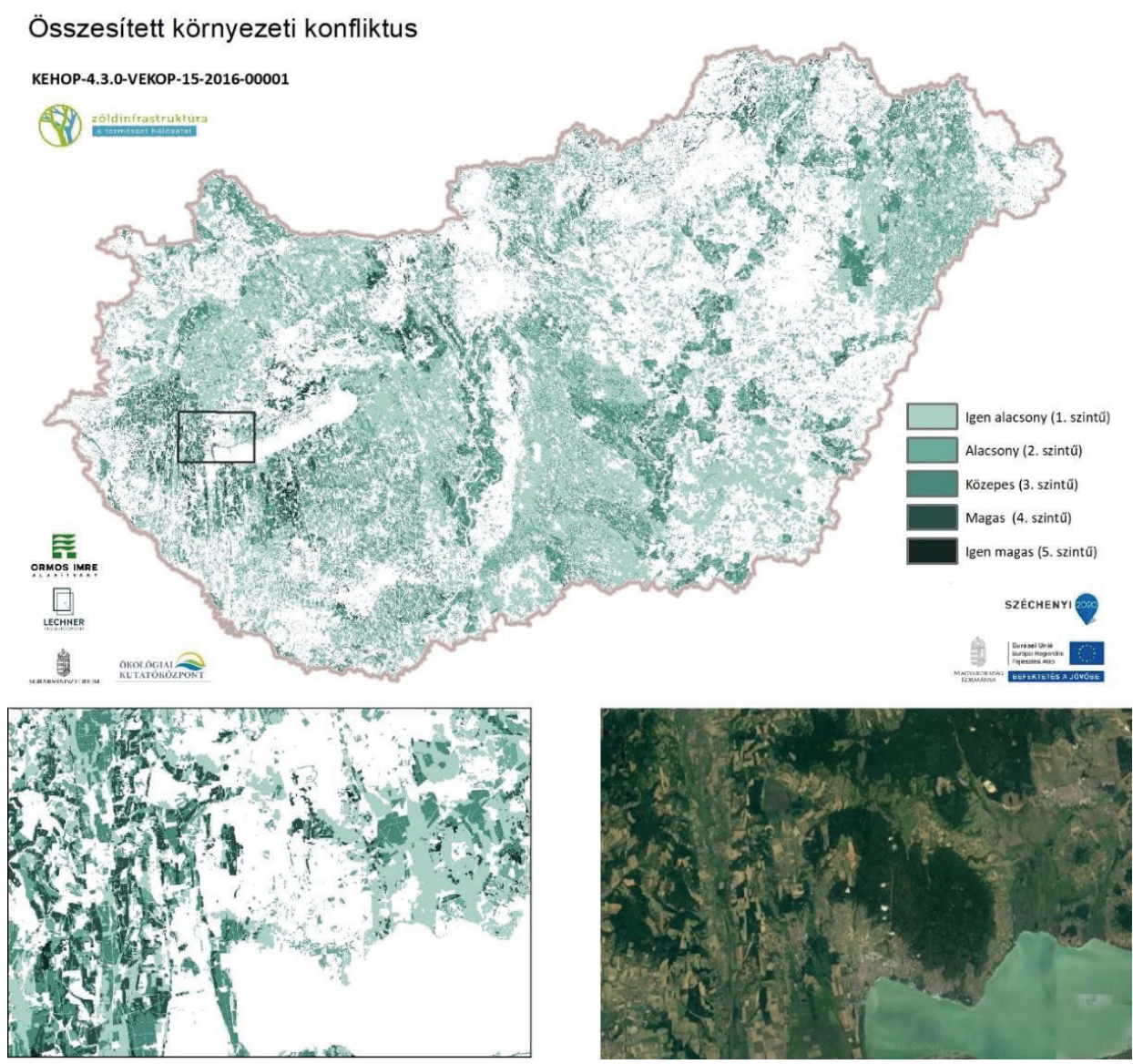

7. ábra. Konfliktus-kompozittérkép: belvíz-veszélyeztetettség, szántók vízminőség-védelmi területen, deflációérzékeny területek, erózió-veszélyeztetett területek, faültetvények. A konfliktus erősségével súlyozott, összesített értékek jelennek meg 0-től 5-ig (az 5 a legmagasabb konfliktus szint).

kutatások is inkább a városi zöldfelületek tervezésére összpontosítottak (Hermoso et al. 2020), így a kifejlesztett módszertan modell is lehet más országok számára.

A három értékelési tengely koncepciójának gyakorlatba való átültetése mellett a legjelentősebb innováció a többrétegü potenciális természetes vegetáció modell (MPNV) alkalmazása a restaurációs célterületek élőhely-priorizálásánál (Somodi et al. 2017). Ez az irány klímaváltozási forgatókönyvek bevonásával klíma-adaptációra képes célélőhely-tervezést is lehetővé tesz a későbbiekben.

A megőrzésre kijelölt területen a kiváló ökológiai állapottal nagy valószínüséggel együtt jár a magas konnektivitás és az ökoszisztéma-szolgáltatások (multifunkcionalitás) magas minősége is. Ez is mutatja, hogy az ökológiai állapot 


\section{Gyepes élőhelyek kialakítására alkalmas potenciális restaurációs területek}

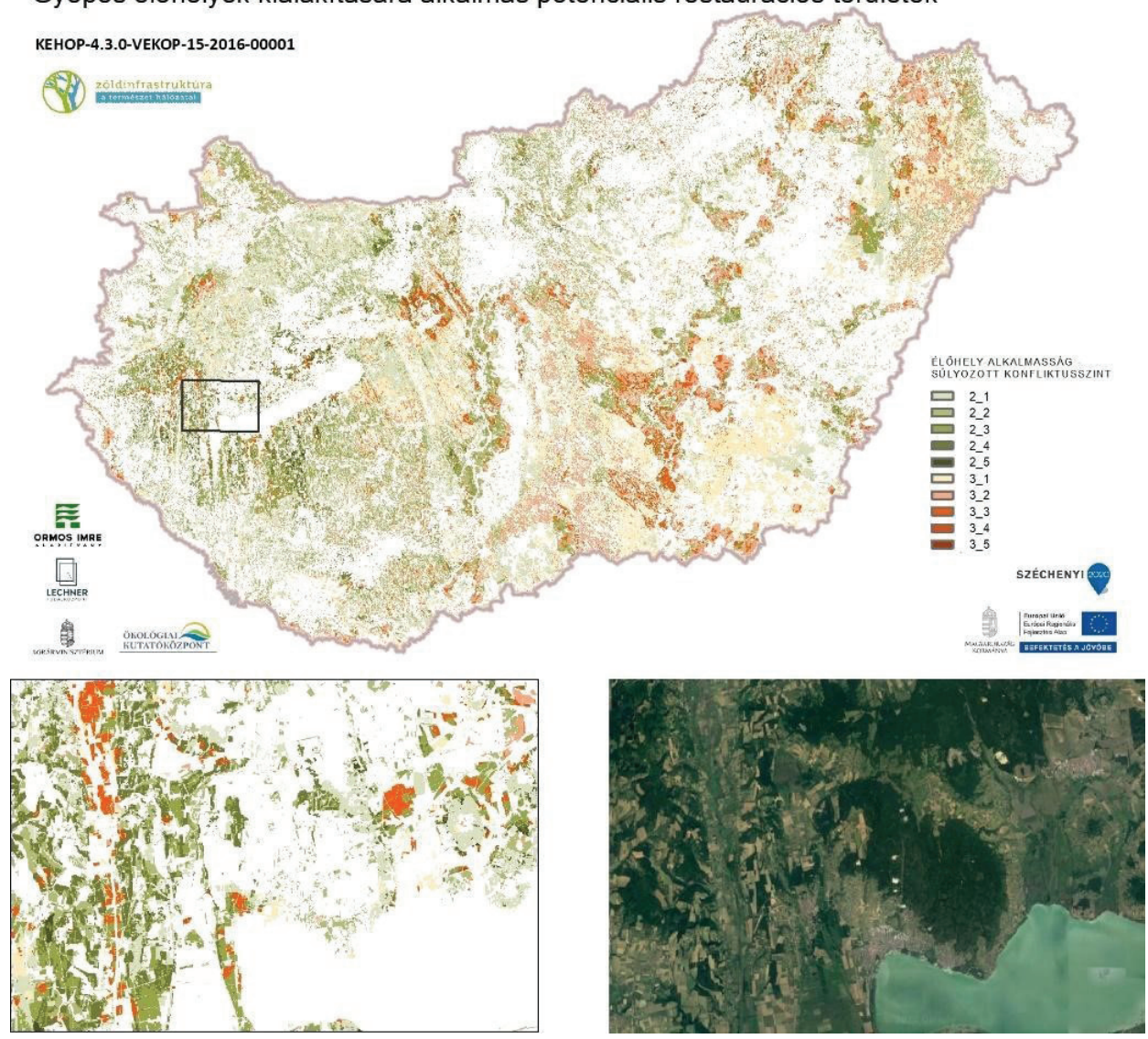

8. ábra. Természetközeli gyepes élőhelyek kialakítására ökológiai szempontból potenciálisan alkalmas restaurációs területek, ahol az ökoszisztéma-váltás megengedett. A jelmagyarázat első száma az MPNV által jósolt élőhelyi alkalmasság valószínűségét jelzi (2: kis valószínüség, 3: közepes és nagy valószínüség), míg a második szám megmutatja, hogy a kialakított környezetikonfliktuskompozittérkép alapján hányas szintü konfliktus van az adott területen.

javítása a multifunkcionalitás növelésének legjobb módja. Jelen kutatás során a multifunkcionalitást az ökoszisztéma-szolgáltatások változatosságával azonosítottuk, ugyanakkor ez gyakran nem egyértelmüen definiált a szakirodalomban (Wang és Banzhaf 2018). A megőrzésre szánt területek térképe alkalmazható a védett területek 30\%-ra történő kiterjesztésének tervezésénél, mely az új EU Biodivezitás Stratégia elöírása 2030-ig. Ugyanakkor látható, hogy a még nem védett, de jó állapotú területek kiterjedése nem biztosítja ezt a fejlesztési célt (és egyéb célokat), a gyengébb állapotú területek restaurációjára is szükség lesz. 
A ZI-fejlesztési terület-lehatárolások alkalmasak a természetvédelmi célú beavatkozások tervezésének támogatására, a konnektivitás-fejlesztés és a fenntarthatósági szempont érvényesítésére a területi fejlesztések, beruházások és különböző területhasználat-típusok helyének meghatározására. Az eredmények alkalmazásához szükség lesz egyedi szakmai döntésekre is. A bemutatott eredmények komplexitása olyan mértékü, ami nem teszi lehetővé minden szempont egyidejü figyelembevételét, ezért sem készült egy, minden réteget magába foglaló összemetszés, az már nehezen lenne értelmezhető. Azonban a konkrét beavatkozások tervezéséhez számos értékelés képzelhető el az alkalmazás során, amikor egy adott régióra, beavatkozási területre, pl. a gyeprestaurációra alkalmas területeket az összesített konfliktusterületekkel, az állami tulajdonú védett területekkel, az alacsony termőképességü területekkel, és az ökológiai folyosókkal együtt elemezve prioritási terület és kívánatos beavatkozástípus egyaránt megadható. Az ismertetett eredmények térinformatikai adatbázisainak (http2) felhasználása még számos szakmai kihívást jelent a jövőben.

Meg kell említeni a ZI-állapotértékelés és a ZI-fejlesztés korlátait is. A bemeneti adatok tekintetében esetenként országos adathiány nehezítette a feldolgozást: pl. a Víz Keretirányelv szerint nem monitorozott víztestekről nincsenek adatok; a gyepek állapotáról nem érhető el olyan szintü állapotértékelés, mint az erdőkről (Tanács et al. 2021). Ez utóbbi hiányosság hozzájárul ahhoz, hogy jelentős gyepterület van a megőrzendő ZI-állapottérben (3. ábra), és főleg erdő az állapotjavításra szánt területeken (4. ábra). Az ökoszisztéma-szolgáltatások indikátorai közül is csak az országosan térképezettek kerülhettek be az elemzésbe. A konnektivitáselemzés többnyire kulcsfajok viselkedése (élőhelypreferencia, terjedési adatok stb.) alapján történik, de új adatok gyüjtésére és részletes modellezésre nem volt módunk, szakértői becslés alapján határoztuk meg az elemzésben jellemzett élöhelyi átjárhatóságot. Az Ökoszisztéma-alaptérkép 2015. évi adatokon alapul, így idővel az adatokat frissíteni szükséges. Remélhetőleg a ZI-fejlesztési javaslatok tovább pontosíthatók, és az adathiányok kezelésére és a ZI-monitorozás megtervezésére is lehetőséget látunk a jövőben egy új projekt keretein belül.

Köszönetnyilvánitás - A kutatás „A közösségi jelentőségü természeti értékek hosszú távú megőrzését és fejlesztését, valamint az EU Biológiai Sokféleség Stratégia 2020 célkitüzéseinek hazai szintủ megvalósítását megalapozó stratégiai vizsgálatok" címú, KEHOP-4.3.0-VEKOP-15-2016-00001 azonosítószámú projekt része volt, amely az Európai Regionális Fejlesztési Alap (ERFA) finanszírozásával, a Széchenyi 2020 részeként, a Környezeti és Energiahatékonysági Operatív Program és a Versenyképes Közép-Magyarország Operatív Program keretében valósult meg. A szakmai munkában részt vettek: Bánhidai András, Bede-Fazekas Ákos, Csákvári Edina, Gallé Róbert, Göncz Annamária, Horváth Ferenc, Jáger Katalin, Kiss Dániel, Lehoczki Róbert, Lengyel Attila, Pataki Róbert, Petrik Ottó, Rimóczi Tamás, Sáradi Nóra, Somodi Imelda, Tanács Eszter és Weiperth András. 


\section{Irodalomjegyzék}

Aronson, J., Alexander, S. (2013): Ecosystem restoration is now a global priority; time to roll up our sleeves. Restoration Ecology 21: 293-296. https://doi.org/10.1111/rec.12011

Csőszi, M., Vaszócsik, V., Török, K., Kollányi, L., Schneller, K., Teleki, M., Bánhidai, A., Kiss, D., Konkoly-Gyuró, É., Jáger, K., Csecserits, A., Szitár, K. (2021): A zöldinfrastruktúra megörzését és fejlesztését biztositó stratégiai keretek és fejlesztési célok, prioritások meghatározása, országos szintü alkalmazása. Jelentés. Agrárminisztérium, Budapest, $219 \mathrm{p}$.

Czúcz, B., Molnár, Zs., Horváth, F., Nagy, G. G., Botta-Dukát, Z., Török, K. (2012): Using the natural capital index framework as a scalable aggregation methodology for regional biodiversity indicators. Journal for Nature Conservation 20: 144-152. https://doi.org/10.1016/j.jnc.2011.11.002

Hermoso, V., Morán-Ordóñez, A., Lanzas, M., Brotons, L. (2020): Designing a network of green infrastructure for the EU. Landscape and Urban Planning 196: 103732. https://doi.org/10.1016/j. landurbplan.2019.103732

Kotiaho, J.S., Kuusela, S., Nieminen, E., Päivinen, J., Moilanen, A., (2016): Framework for Assessing and Reversing Ecosystem Degradation. Report of the Finnish Restoration Prioritization Working Group on the Options and Costs of Meeting the Aichi Biodiversity Target of Restoring at Least 15 Percent of Degraded Ecosystems in Finland. Ministry of Environment, Helsinki, 65 p.

Kovács-Hostyánszki, A., Bereczki, K., Czúcz, B., Fabók, V., Fodor, L., Kalóczkai, Á., Kiss, M., Koncz, P., Kovács, E., Rezneki, R., Tanács, E., Török, K., Vári, Á., Zölei, A., Zsembery, Z. (2019): Nemzeti ökoszisztéma-szolgáltatás térképezés és értékelés, avagy a természetvédelem országos programja. Természetvédelmi Közlemények 25: 80-90. https://doi.org/10.20332/tvkinatconserv.2019.25.80

Somodi, I., Molnár, Zs., Czúcz, B., Bede-Fazekas, Á., Bölöni, J., Pásztor, L., Laborczi, A., Zimmermann, N. E. (2017): Implementation and application of multiple potential natural vegetation models - a case study of Hungary. Journal of Vegetation Science 28: 1260-1269. https://doi. org/10.1111/jvs. 12564

Szitár, K., Csőszi M., Vaszócsik V., Schneller K., Csecserits A., Kollányi L., Teleki M., Kiss D., Bánhidai A., Jáger K., Petrik O., Pataki R., Lehoczki R., Halassy M., Tanács E., Kertész M., Csákvári E., Somodi I., Lengyel A., Gallé R., Weiperth A., Konkoly-Gyúró É., Máté K., Keszthelyi Á. B., Török K. (2021): Az országos zöldinfrastruktúra-hálózat kijelölésének módszertana többszempontú állapotértékelés alapján. Természetvédelmi Közlemények 27: 145-157. https:// doi.org/10.20332/tvk-jnatconserv.2021.27.145

Tanács, E., Bede-Fazekas, Á., Standovár, T., Pásztor, L., Szitár K., Csecserits, A., Kiss, M., Vári, Á. (2021): Az általános ökoszisztéma-állapot indikátorok térképezésének módszertana. Jelentés. Agrárminisztérium, Budapest, 154 p. https://doi.org/10.34811//osz.allapot.modszer.tanulmany

Wang, J., Banzhaf, E. (2018): Towards a better understanding of Green Infrastructure: A critical review. Ecological Indicators 85: 758-772. https://doi.org/10.1016/j.ecolind.2017.09.018

Weber, T., Sloan, A., Wolf, J. (2006). Maryland's Green Infrastructure Assessment: Development of a comprehensive approach to land conservation. Landscape and Urban Planning 77: 94-110. https://doi.org/10.1016/j.landurbplan.2005.02.002

Zhang, Z., Meerow, S., Newell, J. P., Lindquist, M. (2019): Enhancing landscape connectivity through multifunctional green infrastructure corridor modeling and design. Urban Forestry \& Urban Greening 38: 305-317. https://doi.org/10.1016/j.ufug.2018.10.014 


\title{
Hivatkozott jogszabályok:
}

$\operatorname{COM}(2013) 249$ EB rendelet. Green Infrastructure (GI) - Enhancing Europe's Natural Capital. $\operatorname{COM}(2019) 640 \mathrm{~EB}$ rendelet. The European Green Deal.

$\operatorname{COM}(2020) 380$ EB rendelet. EU Biodiversity Strategy for 2030 - Bringing nature back into our lives.

$\operatorname{COM}(2021) 82 \mathrm{~EB}$ rendelet. Forging a climate-resilient Europe — the new EU Strategy on Adaptation to Climate Change.

Internetes források:

http1: http://termeszetem.hu/hu (Hozzáférés dátuma: 2021. 11. 11.)

http2: http://alapterkep.termeszetem.hu/ (Hozzáférés dátuma: 2021. 11. 11.)

\section{Target areas for green infrastructure development in Hungary}

\author{
Katalin Török ${ }^{1}$, Mónika Csőszi ${ }^{2}$, Vilja Vaszócsik², Krisztián \\ Schneller², Mónika Teleki², László Kollányi ${ }^{3}$ Ákos Keszthelyi ${ }^{3}$, \\ Klaudia Máté ${ }^{3}$, Anikó Csecserits ${ }^{1}$, Melinda Halassy ${ }^{1}$, \\ Miklós Kertész ${ }^{1}$ \& Katalin Szitár ${ }^{1}$ \\ ${ }^{1}$ Centre for Ecological Research, Institute of Ecology and Botany, \\ H-2163 Vácrátót, Alkotmány u. 2-4, Hungary \\ ${ }^{2}$ Lechner Knowledge Centre, H-1111 Budapest, Budafoki út 59, Hungary, \\ H-1149 Budapest, Bosnyák tér 5, Hungary \\ ${ }^{3}$ Ormos Imre Charitable Trust, H-1118 Budapest, Villányi út 29-43, Hungary \\ E-mail:torok.katalin@ecolres.hu
}

To reverse the decline of biodiversity, natural capital has to be improved. The EU Biodiversity Strategy seeks to achieve this by green infrastructure development. The identification and assessment of national green infrastructure elements and proposals for their development have three main aspects: ecological state, ecosystem services and connectivity. Our study developed a unified evaluation system of the mapped ecosystem types that resulted in the delineation of areas for conservation or potential improvement, with or without ecosystem type change. The areas for potential green infrastructure development cover a substantial part of the country $(88 \%)$. The areas fit for improvement are further prioritized by the use of different drivers of conflict. The identification of the suitable ecosystem types to be restored was carried out with the help of the multiple potential vegetation model. The results are suitable for application in practical nature conservation and land use planning.

Keywords: connectivity, decision support, EU Biodiversity Strategy, ecological state, ecosystem service, land use, multifunctionality, multiple potential natural vegetation model 